\title{
A comparison of the ultrasound-guided modified-thoracolumbar interfascial plane block and wound infiltration for postoperative pain management in lumbar spinal surgery patients
}

\author{
Lomber spinal cerrahi yapılan hastalarda postoperatif analjezi yönetimi için \\ ultrason eşliğinde yapılan modifiye-torakolomber interfasiyal plan bloğu ve yara yeri \\ infiltrasyonunun karşılaştırılması: Prospektif, randomize çalışma
}

\author{
(D) Mürsel EKINCi,' (D) Bahadır ÇifTÇi,, 'D Erkan Cem ÇELiK, ${ }^{2}$ (D) Ahmet Murat YAYIK, ${ }^{2}$ (D) Alican TAHTA, ${ }^{3}$ \\ (D) Yunus Oktay ATALAY ${ }^{1}$
}

\begin{abstract}
Summary
Objectives: Pain management is an important issue following lumbar spinal surgery. Wound infiltration is a technique that a local anesthetic solution is infiltrated into the tissues around the surgical area. Previous studies reported that US-guided modified thoracolumbar interfacial plane (mTLIP) block after lumbar spinal surgery provided effective analgesia. In this study, we aimed to compare the analgesic efficacy of the US-guided mTLIP block and wound infiltration following lumbar disc surgery.

Methods: 60 patients aged 18-65 years, ASA classification I-II, and scheduled for lumbar disc surgery under general anesthesia were included in the study. US-guided mTLIP block was performed via the lateral approach in group T ( $\mathrm{n}=30)$, and wound infiltration was performed in group W $(n=30)$. Opioid consumption, postoperative pain scores and adverse effects of opioids, such as allergic reactions, nausea, and vomiting, were recorded.

Results: Opioid consumption and the use of rescue analgesia were significantly lower in group $\mathrm{T}$ in all the postoperative periods $(1,2,4,8,16$, and $24 \mathrm{~h})(\mathrm{p}<0.05)$. The VAS scores for pain during mobility and while at rest were significantly lower in group T than those in group W $8 \mathrm{~h}$ after the surgery $(p<0.05)$. The incidences of nausea, vomiting, and itching in group W were higher than the incidences in group $\mathrm{T}$.

Conclusion: The mTLIP block provides effective analgesia for the first $24 \mathrm{~h}$ following lumbar disc surgery, and it may be an alternative to wound infiltration for pain management.
\end{abstract}

Keywords: Lumbar spinal surgery, modified thoracolumbar interfascial plane block; postoperative analgesia; wound infiltration.

Özet

Amaç: Lomber spinal cerrahi sonrası analjezi yönetimi önemli bir konudur. Yara yeri infiltrasyonu, lokal anesteziğin cerrahi alan etrafındaki dokulara infiltre edildiği bir tekniktir. Daha önceki klinik çalışmalar, lomber spinal cerrahi sonrası ultrason (US) eşliğinde yapılan modifiye torakolomber interfasiyal plan (mTLIP) bloğunun etkili analjezi sağladığını göstermektedir. Çalışmamızda lomber disk cerrahisi sonrası US eşliğinde mTLIP bloğun ve yara infiltrasyonunun analjezik etkinliğini karşılaştırmayı amaçladık. Gereç ve Yöntem: Çalışmaya, 18-65 yaş arası, ASA I -II sınıfında olan ve genel anestezi altında lomber disk cerrahisi planlanan 60 hasta dahil edildi. Anestezi indüksiyonu yapılıp pron pozisyona alındıktan sonra T grubuna $(n=30)$ lateral yaklaşımla US eşliğinde mTLIP blok, W grubunda ise $(n=30)$ yara yeri infiltrasyonu yapıldı. Opioid tüketimi, postoperatif ağrı skorları ve yan etkiler (allerjik reaksiyon, bulantı, kusma) kaydedildi.

Bulgular: Postoperatif tüm zaman aralıklarında (1, 2, 4, 8, 16 ve 24 saat) opioid tüketimi ve kurtarıcı analjezi kullanımı grup T'de anlamlı olarak düşüktü $(p<0.05)$. İstirahat ve aktivite sırasındaki VAS skorları postoperatif ilk 8 saatte Grup T'de grup W ya göre anlamlı derecede düşüktü $(p<0.05)$. Grup W da bulantı, kusma ve kaşıntı insidansı grup T'den daha yüksekti.

Sonuç: mTLIP blok, lomber disk ameliyatı yapılan hastalarda postoperatif ilk 24 saat boyunca etkili bir analjezi sağlamaktadır ve analjezi yönetimi için yara yeri infiltrasyonuna alternatif olarak uygulanabilir.

Anahtar sözcükler: Lomber spinal cerrahi; modifiye torakolomber interfasiyal plan bloğu; postoperatif analjezi; yara yeri infiltrasyonu.

\footnotetext{
'Department of Anesthesiology and Reanimation, İstanbul Medipol University Faculty of Medicine, Mega Medipol University Hospital, İstanbul, Turkey 2Department of Anesthesiology and Reanimation, Erzurum Regional Training and Research Hospital, Erzurum, Turkey ${ }^{3}$ Department of Neurosurgery, İstanbul Medipol University, Mega Medipol University Hospital, İstanbul, Turkey
}

Submitted (Başvuru tarihi) 23.10.2019 Accepted after revision (Düzeltme sonrası kabul tarihi) 19.12.2019 Available online date (Online yayımlanma tarihi) 30.04.2020

Correspondence: Dr. Bahadır Çiftçi. Medipol Mega Üniversite Hastanesi, Anesteziyoloji ve Reanimasyon Kliniği, Bağcılar, İstanbul, Turkey.

Phone: +90 - 532 - 5034428 e-mail: bciftci@medipol.edu.tr, baha_cftci@hotmail.com

๑) 2020 Turkish Society of Algology 


\section{Introduction}

Lumbar discectomy surgey is one of the most common surgeries performed for leg and back pain. Postlumbar surgery pain can be severe and may progress to chronic pain during the postoperative period. ${ }^{[1]}$ Therefore, pain management is important. Effective postoperative pain management enables early mobilization and shorter durations of hospital stays and may also reduce hospitalization-related complications, such as infections and thromboembolism. ${ }^{[1-3]}$

The most common analgesic agents used postoperatively are opioids. ${ }^{[4]}$ However, parenteral opioids may result in undesirable adverse events, such as nausea, vomiting, itching, sedation, and respiratory depression. ${ }^{[4]}$ Various methods are available to reduce the use of systemic opioids in postoperative pain management, one of which is local anesthetic infiltration (wound infiltration) into the operation site. Several studies reported that wound infiltration can reduce opioid consumption following surgery. ${ }^{[5-7]}$ Regional anesthesia techniques can also be used to manage postoperative pain. Such techniques have a high success rate, especially if they are applied with ultrasound (US) guidance, as US improves visualization, thereby reducing potential complications. Thoracolumbar interfascial plane (TLIP) block was first described by Hand et al. in 2015. ${ }^{[8]}$ In this technique, a local anesthetic solution is injected between the multifidus and logissimus muscles nearly at the level of the third lumbar vertebra (classic technique). However, there is a risk of neuroaxial injury in this technique, and sonographic imaging of this technique may be difficult. ${ }^{[9]}$ Therefore, Ahiskalioglu et al. ${ }^{[9,10]}$ described the US-guided modified-TLIP (mTLIP) block. Using their modified technique, a local anesthetic solution was injected between the longissimus and iliocostalis muscles. They reported that the sonographic visualization was easier and the complication rate was lower than the classic technique. ${ }^{[10]}$ Previous research reported that US-guided mTLIP block after lumbar spinal surgery provided effective analgesia. ${ }^{[1]]}$ In this study, we compared the analgesic efficacy of the USguided mTLIP block and wound infiltration following single-level lumbar disc surgery. The primary aim was to compare postoperative opioid consumption. The secondary aim was to evaluate postoperative pain scores and adverse effects of opioids, such as allergic reactions, nausea, and vomiting.

\section{Material and Methods}

Ethical approval for this study was provided by the Clinical Research Ethical Committee of Istanbul Medipol University, Istanbul, Turkey. All the patients provided written informed consent.

60 patients underwent lumbar spinal surgery were included in the study. The patients were aged 18-65 years, American Society of Anesthesiologists classification I-II, and scheduled for single-level lumbar disc surgery under general anesthesia. The exclusion criteria were a history of bleeding diathesis, anticoagulant treatment, known local anesthetics and opioid allergies, skin infections at the site of a needle puncture, pregnancy or lactation, and refusal to accept the procedure. The patients were randomly divided into two groups using a randomizing computer program: a TLIP block group (group T) and a wound infiltration group (group W), with 30 patients in each group).

\section{General anesthesia}

After placement of a peripheral IV cannula, the patients were monitored with electrocardiography (ECG), noninvasive blood pressure, and pulse oximetry $\left(\mathrm{SpO}_{2}\right)$. Midazolam (2 mg) was administered intravenously. General anesthesia was induced via IV administration of propofol (2-2.5 mg/kg) and fentanyl $(1-1.5 \mu \mathrm{g} / \mathrm{kg})$. After administration of rocuronium bromide $(0.6 \mathrm{mg} / \mathrm{kg})$, orotracheal intubation was performed. The patients were placed in the prone position. Anesthesia maintenance was achieved with sevoflurane in a mixture of oxygen and fresh air, and remifentanil was administered at an infusion rate of $0.01-0.1 \mu \mathrm{g} / \mathrm{kg} / \mathrm{min}$.

The patients' heart rates, respiratory rates, peripheral oxygen saturation, invasive arterial pressures, and end-tidal carbon dioxide levels were recorded at 5-min intervals throughout the surgery. Controlled mechanical ventilation was initiated with a tidal volume of $8 \mathrm{ml} / \mathrm{kg}$, fresh gas flow rate of $2 \mathrm{~L}$ per min, respiratory rate of 12 breaths per min (I:E ratio of 1:2), peak airway pressure of $30 \mathrm{~cm} \mathrm{H}_{2} \mathrm{O}$, and end tidal carbon dioxide $\left(\mathrm{CO}_{2}\right)$ value of $30-35 \mathrm{mmHg}$. All the patients underwent microscopically lumbar discectomy and partial hemilaminectomy surgery using the same technique, and the same surgical team performed all the surgeries. 

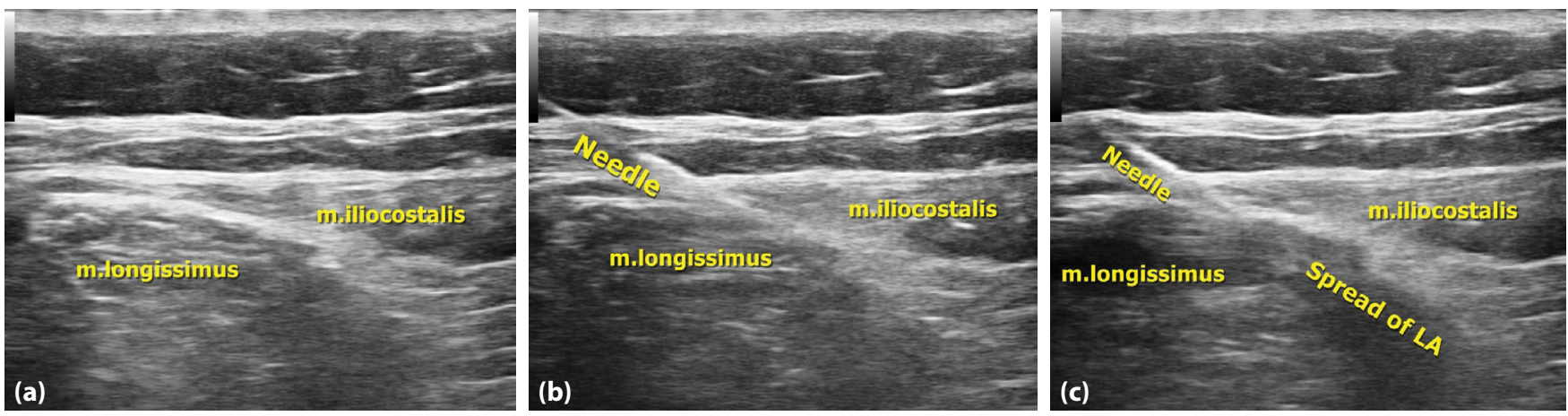

Figure 1. (a) Sonographic anatomy of the block region. (b) The needle direction between longissimus and iliocostalis muscles. (c) Spread of local anesthetic. LA indicates local anesthetic.

\section{Block technique}

After the induction of anesthesia and placement of the patient in a prone position, US-guided mTLIP block was performed via the lateral approach in group $T$, and wound infiltration was performed in group W.

In group T, the block was performed bilaterally under aseptic conditions using the GE Vivid $Q^{\circledR}$ US device (GE Healthcare, USA) with a high-frequency $12-\mathrm{MHz}$ linear US probe. The probe was covered with a sterile sheath and placed vertically at the L3 vertebrae level. After visualizing the hyperechoic shadow of the spinous process and interspinous muscles as an anatomical guide point, the probe was moved forward in a lateral direction to visualize the longissimus and iliocostal muscles (Fig. 1a). As shown in Figure 1b, using the in-plane technique, a 22-G, 50-mm block needle (Braun Stimuplex Ultra 360, Germany) was inserted between the muscles in a medial-to-lateral direction in the interfascial plane..$^{[9,10]}$ Once the needle tip was placed within the interfascial plane and after careful aspiration to rule out intravascular needle placement, $2 \mathrm{ml}$ of saline was injected to confirm the accuracy of the injection site. A dose of $0.25 \%$ bupivacaine $(20 \mathrm{ml})$ was then injected in each side (total $40 \mathrm{ml}$ ) (Fig. 1c).

In group $\mathrm{W}$, a dose of $0.5 \%$ bupivacaine $(20 \mathrm{ml})$ was injected for wound infiltration into the surgery site. All the patients received IV paracetamol $(1 \mathrm{~g}) 30 \mathrm{~min}$ before the end of the surgery, as well $4 \mathrm{mg}$ of ondansetron IV. At the end of the surgery, neuromuscular blockage was antagonized using IV atropine (0.015 $\mathrm{mg} / \mathrm{kg}$ ) and neostigmine $(0.03 \mathrm{mg} / \mathrm{kg})$.

The patients were extubated after visualizing sufficient spontaneous respiration and transferred to the postanesthesia care unit. After they attained a modified Aldrete score of 12, the patients were discharged from the unit.

For postoperative analgesia, a dose of $1 \mathrm{~g}$ of paracetamol (IV) was administered routinely, every $8 \mathrm{~h}$. All the patients received fentanyl via a patientcontrolled analgesia device. The protocol was a 20 mcg bolus without an infusion dose, 20-min lockout time, and 4-h limit. An anesthesiologist blinded to the procedure performed the postoperative pain assessment using the visual analogue scale (VAS) ( $0=$ no pain, $10=$ the most severe pain felt). The VAS scores at rest and during mobilization were recorded at postoperative $1,2,4,8,16$, and $24 \mathrm{~h}$. In cases where VAS scores were $\geq 4,0.5 \mathrm{mg} / \mathrm{kg}$ of meperidine was administered intravenously.

The sedation level was assessed using a 4-point sedation scale ( $0=$ awake, eyes open, $1=$ sleepy but responding to verbal stimulus, $2=$ sleepy and difficult to evoke a response, $3=$ sleepy, not aroused by shaking). Postoperative opioid consumption, adverse events, such as nausea, vomiting, and itching, and block-related complications were recorded.

\section{Statistical analysis}

A power analysis was performed to determine the required sample size to assess total postoperative opioid consumption. The effect size was 3.44 (95\% confidence interval), therefore indicating that the sample size was sufficient. Statistical analyses were performed using SPSS 20.0 for Windows (IBM, NY, USA). The Kolmogorov-Smirnov test was used to evaluate the data distribution. Pearson's chi-square test was applied to categorical data in the groups. The student's $T$ test was used to check differences between the groups, at a significance level of 5\% 
Table 1. Comparison of patients's characteristics, surgical duration and level of surgery between group T and group W

\begin{tabular}{lccr}
\hline & Group T (n=30) & Group W (n=30) & p \\
\hline Age & $46.90 \pm 9.46$ & $47.90 \pm 10.819$ & $0.705^{\alpha}$ \\
Male/Female & $13 / 17$ & $16 / 14$ & $0.438^{\beta}$ \\
ASA I/II & $15 / 15$ & $17 / 13$ & $0.605^{\beta}$ \\
Weight (kg) & $76.33 \pm 10.68$ & $81.27 \pm 12.03$ & $0.098^{a}$ \\
Height (cm) & $169.63 \pm 9.66$ & $168.10 \pm 10.17$ & $0.552^{a}$ \\
Duration of anesthesia & $116.76 \pm 27.26$ & $108.76 \pm 21.08$ & $0.209^{a}$ \\
Surgical duration (min) & $85.43 \pm 24.45$ & $74.43 \pm 18.82$ & $0.056^{\alpha}$ \\
Level of surgery (L5-S1 /L4-L5/L3-L4/L2-L3) & $2 / 22 / 6 / 0$ & $1 / 14 / 14 / 1$ & $0.097^{\beta}$ \\
\hline
\end{tabular}

Values are expressed mean \pm standart deviation or number. ASA: American Society of Anesthesiologist; kg; kilogram; $\mathrm{cm}$ : centimeter; min: minutes; L: Lumbar; S: Sacral; $\alpha$ : $p>0.05$ Student's T test between groups; $\beta$ : $p>0.05$ Chi-square test between groups.

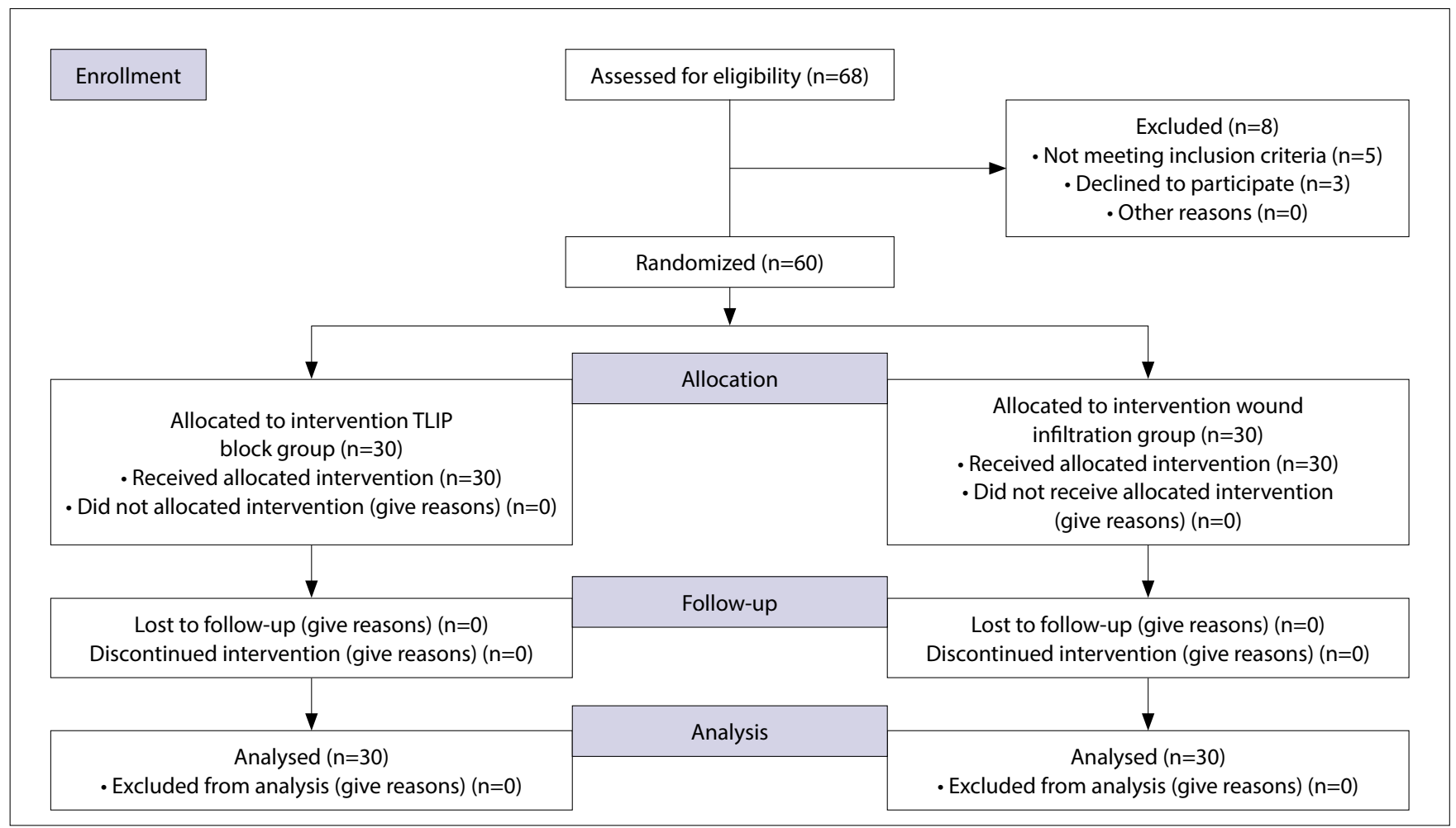

Figure 2. CONSORT flow diagram of the study.

for normally distributed continuous variables. Descriptive statistics are expressed as mean \pm standard deviation.

\section{Results}

This study comprised 60 patients, with 30 (50\%) patients in each group. There were no statistically significant intergroup differences in terms of age, weight, length, American Society of Anesthesiologists status, duration of anesthesia, duration of surgery, and surgical level ( $p>0.05$ ) (Table 1). The results are presented in a Consolidated Standards of Reporting Trials flow diagram in Figure 2. Opioid consumption was significantly lower in group $T$ as compared with that in group $\mathrm{W}$ in all the postoperative periods $(1,2,4,8,16$, and $24 h)(p<0.05)$. The use of rescue analgesia in group $\mathrm{T}$ was significantly lower than that in group W $(p<0.05)$ (Table 2$)$. The VAS scores for pain during mobility and while at rest were significantly lower in group $T$ than those in group W $8 \mathrm{~h}$ after the surgery $(\mathrm{p}<0.05)$ (Table 3 ). The incidences of nausea, vomiting, and itching in group W were higher than those in group T. There were no between-group differences in other adverse effects (Table 4). 
Table 2. Comparison of opioid consumptions and rescue anlagesia between group $\mathrm{T}$ and group $\mathrm{W}$

\begin{tabular}{lccc}
\hline Opioid consumption & Group T $(\mathbf{n = 3 0})$ & Group W $(\mathbf{n = 3 0})$ & $\mathbf{p}$ \\
\hline $1^{\text {st }}$ hour & $5.3 \pm 11.6$ & $42.0 \pm 15.1$ & $<0.001^{\text {a }}$ \\
$2^{\text {nd }}$ hour & $11.3 \pm 19.4$ & $82.6 \pm 2.61$ & $<0.001^{\text {a }}$ \\
$4^{\text {th }}$ hour & $18.0 \pm 24.2$ & $129.3 \pm 43.2$ & $<0.001^{a}$ \\
$8^{\text {th }}$ hour & $30.0 \pm 27.6$ & $168.0 \pm 54.2$ & $<0.001^{a}$ \\
$16^{\text {th }}$ hour & $50.6 \pm 26.1$ & $198.6 \pm 62.5$ & $<0.001^{\text {a }}$ \\
$24^{\text {th }}$ hour & $58.0 \pm 32.0$ & $223.3 \pm 74.1$ & $<0.001^{\text {a }}$ \\
Rescue analgesia $(Y / N)$ & $7 / 23$ & $15 / 15$ & $0.032^{\beta}$
\end{tabular}

Values are expressed mean \pm standart deviation. $\alpha: p<0.001$ Student's T test between groups; $\beta: p<0.05$ Chi Square Test between groups.

Table 3. Comparison of VAS scores between group T and group $\mathrm{W}$

\begin{tabular}{|c|c|c|c|}
\hline VAS (hour) & Group T $(n=30)$ & Group W $(n=30)$ & $\mathbf{p}$ \\
\hline Passive 0 & $0.60 \pm 0.85$ & $3.77 \pm 1.27$ & $<0.001^{a}$ \\
\hline Passive $2^{\text {nd }}$ & $0.37 \pm 0.61$ & $2.80 \pm 1.27$ & $<0.001^{\mathrm{a}}$ \\
\hline Passive $4^{\text {st }}$ & $0.20 \pm 0.48$ & $2.63 \pm 0.99$ & $<0.001^{a}$ \\
\hline Passive $8^{\text {st }}$ & $0.50 \pm 0.57$ & $1.70 \pm 0.98$ & $<0.001^{a}$ \\
\hline Passive $16^{\text {st }}$ & $1.23 \pm 1.20$ & $1.27 \pm 0.94$ & $0.906^{\beta}$ \\
\hline Passive $24^{\text {st }}$ & $0.73 \pm 0.69$ & $1.00 \pm 0.64$ & $0.127^{\beta}$ \\
\hline Active 0 & $1.30 \pm 1.39$ & $4.60 \pm 1.22$ & $<0.001^{a}$ \\
\hline Active $2^{\text {nd }}$ & $0.93 \pm 1.04$ & $3.57 \pm 0.97$ & $<0.001^{a}$ \\
\hline Active $4^{\text {st }}$ & $0.97 \pm 0.96$ & $3.47 \pm 1.04$ & $<0.001^{a}$ \\
\hline Active $8^{\text {st }}$ & $1.20 \pm 0.88$ & $2.37 \pm 1.03$ & $<0.001^{a}$ \\
\hline Active $16^{\text {st }}$ & $1.97 \pm 1.56$ & $1.77 \pm 1.10$ & $0.569^{\beta}$ \\
\hline Active $24^{\text {st }}$ & $1.13 \pm 0.90$ & $1.53 \pm 0.90$ & $0.090^{\beta}$ \\
\hline
\end{tabular}

Values are expressed mean \pm standart deviation. VAS: Visual analog pain scale; $\alpha: p<0.001$ Student's T test between groups; $\beta$ : $p>0.05$ Student's T test between groups.

\section{Discussion}

This study compared the analgesic efficacy of an US-guided mTLIP block with wound infiltration for postoperative analgesia management after lumbar discectomy/hemilaminectomy. The results demonstrated that MTLIP block provided better analgesia, with decreased VAS scores and opioid consumption, in addition to a reduced incidence of adverse effects, as compared with wound infiltration. There were no complications related to the block or local anesthetics.

Wound infiltration is a technique in which a local anesthetic solution is infiltrated into the tissues around the surgical area. Many studies have reported the poor effectiveness of wound infiltration in terms of opioid consumption. ${ }^{[2,6,12-14]}$ Its underlying mechanism depends on absorption of the local anesthetic solution by the injected tissues. Although wound in-
Table 4. Comparison of side effects between group $T$ and group $\mathrm{W}$

\begin{tabular}{lccc}
\hline & $\begin{array}{c}\text { Group T } \\
(\mathbf{n}=\mathbf{3 0})\end{array}$ & $\begin{array}{c}\text { Group W } \\
(\mathbf{n}=\mathbf{3 0})\end{array}$ & $\mathbf{p}$ \\
\hline Breathing depression & 0 & 0 & $1.000^{\alpha}$ \\
Sedation/Confusion & 0 & 0 & $1.000^{\alpha}$ \\
Somnolence & 0 & 0 & $1.000^{\alpha}$ \\
Urinary retention & 0 & 0 & $1.000^{\alpha}$ \\
Consitpation & 0 & 0 & $1.000^{\alpha}$ \\
Nausea & 2 & 8 & $0.038^{\beta}$ \\
Vomiting & 0 & 5 & $0.020^{\beta}$ \\
Pruritis & 1 & 6 & $0.044^{\beta}$ \\
\hline
\end{tabular}

Values are expressed as a number. $a: p>0.05$ Chi-square test between groups; $\beta$ : $p<0.05$ Chi-square test between groups.

filtration is easy and simple to perform, it has a number of disadvantages. First, the local anesthetic is in- 
jected blindly into the tissues. Second, the method provides analgesia only at the site of administration.

The ventral motor root and dorsal sensory root fuse to form the spinal nerve. The spinal nerve then divides into two rami after exiting the intervertebral foramen: the large ventral ramus and smaller dorsal ramus. The dorsal ramus runs around the facet joints, innervates ligaments, joints, and paravertebral muscles; and provides cutaneous sense from the vertex to the coccyx. ${ }^{[15]}$ These nerves can be blocked by USguided regional anesthetic techniques (interfascial plane blocks). Such techniques have a number of advantages. For example, they are easy to perform and provide improved visualization and reduced complication rates. ${ }^{[9,10,16-18]}$ TLIP block is a type of interfascial plane block that targets the dorsal rami of the thoracolumbar nerves.$^{[8]}$ In this technique, a local anesthetic solution is injected between the multifidus and logissimus muscles by advancing the needle from the lateral to the medial side (classic technique). A retrospective study reported that TLIP block was effective in analgesia after lumbar laminoplasty surgery. ${ }^{[16]}$ However, there is a risk of inadvertently inducing neuroaxial anesthesia when advancing the needle from the lateral side to the medial side during TLIP block, and sonographic imaging of the longissimus and iliocostalis muscles can be easier than imaging the multifidus and longissimus muscles. Therefore Ahiskalioglu et al. ${ }^{[9,10]}$ described a US-guided mTLIP block via a lateral approach. Using their modified technique, a local anesthetic solution was injected between the longissimus and iliocostalis muscles, and the needle was advanced medial to lateral. As with the classic approach, a number of studies demonstrated the analgesic effectiveness of the mTLIP block after lumber spinal surgery. ${ }^{[11,17]}$ Thus, we used the mTLIP block in this study. In common with the literature, we found that the MTLIP block was an effective postoperative pain management technique after lumbar surgery. In a cadaveric study in which the mTLIP technique was used, the injected solution spread over the transverse process and colored the dorsal rami between the first and fourth lumbar nerves. ${ }^{[18]}$ This finding supports that the mTLIP block provides more effective analgesia than wound infiltration.

In the literature, in a randomized trial evaluating the efficacy of US-guided mTLIP block for postoperative analgesia after spinal surgery, Ahiskalioglu et al. ${ }^{[19]}$ per- formed a bilateral mTLIP block and reported that the mTLIP block decreased opioid consumption and VAS scores compared to the fentanyl PCA control group. Ueshima et al. also performed a mTLIP block in two patients following lumbar spinal surgery and reported that it had a successful analgesic effect postoperatively. ${ }^{[17]}$ In another case report, Li et al. performed a bilateral mTLIP block in two patients who underwent multilevel spinal fusion surgery. ${ }^{[11]}$ They reported effective pain relief from activity-related pain for $24 \mathrm{~h}$ and effective pain relief from rest-related pain for 48 h. Other research demonstrated that the mTLIP block was an effective analgesia technique not only in acute postoperative pain but also in chronic low back pain. ${ }^{[20]}$ These findings support those of the present study.

In a study, Ince et al. ${ }^{[21]}$ compared the efficacy of USguided TLIP block and wound infiltration for postoperative analgesia following single-level discectomy surgery. They reported that wound infiltration is a simple method compared with TLIP block and it is an effective technique for acute pain management after lumbar discectomy. There are some differencies between this correspondence and our randomized study. Firstly, we performed mTLIP block via lateral approach. mTLIP block has been defined due to it is a simplier method than classical approach. Thus, it may be performed easier. Secondly, the number of patients is 40 in that correspondence. However, we studied this randomized trial in 60 patient. On the other hand, only discectomy was performed as surgical technique in the correspondence. In our study both discectomy and hemilaminectomy were performed surgically. Lastly, our results has showed that mTLIP block provides more effective analgesia than wound infiltration following single-level lumbar spinal surgery. In terms of this, larger sample studies with larger patient populations may be needed to explain these different results.

This study has some limitations. First, we evaluated the analgesic efficacy of the mTLIP block technique for only $24 \mathrm{~h}$ following surgery. Thus, the analgesic efficacy of the mTLIP block technique for longer periods, as well as for chronic pain, is unclear. Second, the present study did no include an assessment of the ideal volume and concentration of local anesthetics during TLIP block. Lastly, it would be useful a contrast medium was added to the mixture followed by an anteroposterior $\mathrm{X}$-ray to understand the the exact spread of the injected solution. 
Further studies with different volumes and concentrations are needed. Studies evaluating the analgesic efficacy of the mTLIP block in different types of lumbar spinal surgical procedures are required.

\section{Conclusion}

To summarize, we conclude that the mTLIP block provides effective analgesia for the first $24 \mathrm{~h}$ following lumbar disc surgery and that it may be an alternative to wound infiltration for pain management after lumbar discectomy and hemilaminectomy surgery.

\section{Ethics Committee Approval: Ethical approval for this study was provided by the Clinical Research Ethical Com- mittee of Istanbul Medipol University (date: 28.12.2018, number: 24).}

\section{Conflict-of-interest issues regarding the authorship or article: None declared.}

Peer-rewiew: Externally peer-reviewed.

Financial Disclosure: The authors declared that this study has received no financial support.

\section{References}

1. McGirt MJ, Ambrossi GL, Datoo G, Sciubba DM, Witham TF, Wolinsky JP, et al. Recurrent disc herniation and long-term back pain after primary lumbar discectomy: review of outcomes reported for limited versus aggressive disc removal. Neurosurgery 2009;64(2):338-45. [CrossRef]

2. Gurbet A, Bekar A, Bilgin H, Ozdemir N, Kuytu T. Preemptive wound infiltration in lumbar laminectomy for postoperative pain: comparison of bupivacaine and levobupivacaine. Turk Neurosurg 2014;24(1):48-53.

3. Efthymiou CA, O'Regan DJ. Postdischarge complications: what exactly happens when the patient goes home? Interact Cardiovasc Thorac Surg 2011;12(2):130-4. [CrossRef]

4. Benyamin R, Trescot AM, Datta S, Buenaventura R, Adlaka R, Sehgal N, Glaser SE, Vallejo R. Opioid complications and side effects. Pain Physician 2008;11(2 Suppl):S105-20.

5. Teddy PJ, Fabinyi GC, Kerr JH, Briggs M. Bupivacaine infiltration after lumbar laminectomy. Local infiltration in the control of early postoperative lumbar laminectomy pain. Anaesthesia 1981;36(4):380-3. [CrossRef]

6. Ersayli DT, Gurbet A, Bekar A, Uckunkaya N, Bilgin H. Effects of perioperatively administered bupivacaine and bupivacaine-methylprednisolone on pain after lumbar discectomy. Spine (Phila Pa 1976) 2006;31(19):2221-6. [CrossRef]

7. Ozyilmaz K, Ayoglu H, Okyay RD, Yurtlu S, Koksal B, Hanci V, et al. Postoperative analgesic effects of wound infiltration with tramadol and levobupivacaine in lumbar disk surgeries. J Neurosurg Anesthesiol 2012;24(4):331-5. [CrossRef]
8. Hand WR, Taylor JM, Harvey NR, Epperson TI, Gunselman RJ, Bolin ED, Whiteley J. Thoracolumbar interfascial plane (TLIP) block: a pilot study in volunteers. Can J Anaesth 2015;62(11):1196-200. [CrossRef]

9. Ahiskalioglu A, Yayik AM, Alici HA. Ultrasound-guided lateral thoracolumbar interfascial plane (TLIP) block: Description of new modified technique. J Clin Anesth 2017;40:62.

10. Ahiskalioglu A, Alici HA, Selvitopi K, Yayik AM. Ultrasonography-guided modified thoracolumbar interfascial plane block: a new approach. Can J Anaesth 2017;64(7):775-6.

11. Li C, Jia J, Qin Z, Tang Z. The use of ultrasound-guided modified thoracolumbar interfascial plane (TLIP) block for multilevel lumbar spinal surgery. J Clin Anesth 2018;46:49-51.

12. Gurbet A, Bekar A, Bilgin H, Korfali G, Yilmazlar S, Tercan $M$. Pre-emptive infiltration of levobupivacaine is superior to at-closure administration in lumbar laminectomy patients. Eur Spine J 2008;17(9):1237-41. [CrossRef]

13. Kjærgaard M, Møiniche S, Olsen KS. Wound infiltration with local anesthetics for post-operative pain relief in lumbar spine surgery: a systematic review. Acta Anaesthesiol Scand 2012;56(3):282-90. [CrossRef]

14. Perera AP, Chari A, Kostusiak M, Khan AA, Luoma AM, Casey ATH. Intramuscular Local Anesthetic Infiltration at Closure for Postoperative Analgesia in Lumbar Spine Surgery: A Systematic Review and Meta-Analysis. Spine (Phila Pa 1976) 2017;42(14):1088-95. [CrossRef]

15. Maigne R. Innervation of vertebral structures. In: Nieves WL, editor. Diagnosis and Treatment of Pain of Vertebral Origin. 2nd ed. CRC Press, Taylor and France Group; 2006. p. 30-41. [CrossRef]

16. Ueshima H, Ozawa T, Toyone T, Otake H. Efficacy of the Thoracolumbar Interfascial Plane Block for Lumbar Laminoplasty: A Retrospective Study. Asian Spine J 2017;11(5):722-5. [CrossRef]

17. Ueshima $\mathrm{H}$, Otake H. Clinical efficacy of modified thoracolumbar interfascial plane block. J Clin Anesth 2016;30:745. [CrossRef]

18. Ueshima $\mathrm{H}$, Otake $\mathrm{H}$. Ultrasound-guided "lateral" thoracolumbar interfascial plane (TLIP) block: A cadaveric study of the spread of injectate. J Clin Anesth 2017;40:54. [CrossRef]

19. Ahiskalioglu A, Yayik AM, Doymus O, Selvitopi K, Ahiskalioglu EO, Calikoglu C, et al. Efficacy of ultrasound-guided modified thoracolumbar interfascial plane block for postoperative analgesia after spinal surgery: a randomizedcontrolled trial. Can J Anaesth 2018;65(5):603-4. [CrossRef]

20. Ahiskalioglu A, Yayik AM, Celik EC, Aydin ME, Uzun G. UItrasound guided modified Thoracolumbar Interfascial Plane block for low back pain management. J Clin Anesth 2019;54:138-9. [CrossRef]

21. Ince I, Atalay C, Ozmen O, Ozturk V, Hassan M, Aksoy M, et al. Comparison of ultrasound-guided thoracolumbar interfascial plane block versus wound infiltration for postoperative analgesia after single-level discectomy. J Clin Anesth 2019;56:113-4. [CrossRef] 